brazilianpoliticalsciencereview

\title{
ARTICLE
}

\section{The Three Achilles' Heels of Brazilian Political Science*}

\author{
André Marenco \\ Universidade Federal do Rio Grande do Sul, Brazil
}

\begin{abstract}
This article intends to analyze the institutionalization of political science in Brazil through the expansion of the graduate system and evaluation process, which promoted research and scientific evaluations of institutions with Master's and doctoral degree programs by an assessment model based on peer reviews and the rating of scientific production. The focus here is on Political Science in comparison with its neighboring disciplines, Sociology and Anthropology. We attempt to consider the timing of the process of academic institutionalization of Political Science, as well as its consequences for the consolidation of the field nowadays.
\end{abstract}

Keywords: Political science, postgraduate system, scientific production, international collaboration.

The origin and formation of the social sciences in Brazil has been the object of deep and rigorous investigations that have brought to light the conditions that marked the work of the founding fathers of social and political thought in Brazil. In this regard, Miceli (1995) emphasises the importance of the creation of academic institutions in São Paulo for the autonomy of the pioneering generations of social scientists, in contrast with the smaller differentiation between social scientists and the political elites of Brazil's other states. Forjaz (1997) highlights the role played in the genesis of Political Science in Brazil by a generation established in Rio de Janeiro and Minas Gerais. 
Trindade $(2007 ; 2012)$ renders this scenario more complex with his more nuanced diagnosis, revealing the great regional diversity in the processes of formation of the social sciences in Brazil, as well as the importance that international circulation had for professionalising researchers and for the constitution of groups geared towards academic research in different institutional and regional contexts. In addition, Lamounier (1982) identifies the two bases that constituted Political Science in Brazil: a tradition of political thought forged between the 1920s and 1960s and the professionalisation that came as a result of the expansion of the academic system in the 1960s and 1970s.

The aim of this article is not to revisit the founding elements of the social sciences in Brazil - a process that has been well documented and analytically unravelled -, but to explore its inflexion, starting from its gradual institutionalisation, particularly after the end of the 1960s. Our intention is to isolate the main expression of this process of institutionalisation - the expansion of the postgraduate system, which brought research and scientific reflection into institutions focused on training masters and doctors and strongly oriented by an assessment model based on peer judgement and the rating of scientific production. The focus here is on Political Science in comparison with its neighbouring disciplines, Sociology and Anthropology. We attempt to consider the timing of the process of academic institutionalisation of Political Science, as well as its consequences for the consolidation of the field nowadays. In the first section, we attempt to retrace the sequence of institutionalisation in the three fields based on an examination of how PhD courses and the training of doctors in Political Science, Sociology and Anthropology were formed. In the second section, we map the Political Science postgraduate programmes - considering the areas and thematic lines present in institutions currently in existence -, as a procedure for assessing their concentration (or diversity) and expansion, as well as the consolidation of a model for evaluating scientific production. Lastly, the text deals with the international impact of the scientific production by the Brazilian Political Science community. The information on the postgraduate programmes was extracted from the database of the Coordenação de Aperfeiçoamento de Pessoal de Nível Superior 
(Capes - Brazilian Federal Agency for the Improvement of Higher Education) ${ }^{1}$, which, in its turn, is updated every year by the Capes Report, containing information presented by the programmes on their activities during that period. Any discrepancies between the information made available by Capes, the postgraduate programmes and those published in the Lattes Platform (CV database) are attributable to the information provided by the programmes. In order to maintain standardisation, unless otherwise stated, the data from Capes were utilised - the same ones that are used for assessing Brazil's postgraduate system.

\section{The institutionalisation of Political Science in Brazil: slow but sure}

To Bulcourf and Vasquez (2004), the institutionalisation of an academic discipline is identified when it differentiates itself from other fields and academic disciplines, producing its own professional skills. As a result of the conformation of a specific professional community, the constitution of shared criteria of professional evaluation and recruitment, followed by the appearance of scientific associations, should be expected. In this sense, shared parameters for assessing merit and academic organisations seem to be the main symptoms of a discipline's institutionalisation.

Of a similar ilk is the demarcation suggested by Pérez-Linãn (2010), for whom high institutionalisation can be recognised by regular, peer reviewed academic publications, professional recognition based on productivity - rather than on teaching or positions assumed in public debate -, low endogeny, high qualification requirements for entering a post and exclusive dedication in order to keep it. Conversely, low or precarious institutionalisation is recognisable when the profession is poorly structured, there is no requirement for exclusive dedication to a post, the academic training is in neighbouring disciplines such as Law, History or Sociology, publications are intermittent and there is no peer-review system, criteria of professional recognition are based on belonging to the "right" circles, there is dilettantism and low specialisation as seen in a wide range of teaching activities and research projects, and a tendency for an essayistic treatment of objects rather than a search for and treatment of empirical evidence.

\footnotetext{
${ }^{1}$ See http://conteudoweb.capes.gov.br/conteudoweb/CadernoAvaliacaoServlet.
} 
Finally, Leite and Codato (2013) associate institutionalisation with discipline autonomy by distinguishing the two dimensions through which this autonomy operates: firstly, (i) an institutional autonomy, marked by an expansion of the postgraduate system through Master's and Doctoral programmes, a rise in "disciplinary" periodicals (as opposed to more general ones) and the creation of scientific associations, such as in the case of the Associação Brasileira de Ciência Política (ABCP - Brazilian Association of Political Science). Parallel to that, (ii) a theoretical-methodological autonomy, entailing a "development of theories, methods and approaches that are particular to it", or, in other words, "that deal with politics as a self-regulating universe", making it "irreducible to other disciplines" (LEITE and CODATO, 2013, p. 01).

Using these notions as a parameter, here we consider disciplinary institutionalisation as a process resulting from two factors: (i) an expansion of the indicators of professionalisation, involving the material bases necessary for academic activity and training professionals involved in research at universities and professional associations, creating a distance from dilettante amateurism; (ii) the consolidation of an institutional assessment system based on peer judgement, as a criterion for constituting academic hierarchies and allocating resources and incentives to academic and research activity.

The main driving force behind this process of institutionalisation of Brazilian Political Science has probably been the assessment of the postgraduate system carried out by Capes since 1976, which considers two aspects: 1) the accreditation of new courses and (2) a triennial evaluation of the performance of all institutions that make up the postgraduate system.

Two criticisms have been made of the inductive effect on the institutionalisation of the Brazilian postgraduate system caused by the Capes assessment. The first is that the rules of the institutional assessment might be an incentive to "productivism". By prioritising quantitative indicators, such as the number of published articles, citations or impact factor, the Capes institutional assessment could end up encouraging quantity of scientific production over quality or originality, as well as the use of subterfuges in order to artificially increase these indicators - such as self-citation, cross referencing or replicating the same piece (BIANCHI, 2014). A second criticism points out that academic institutionalisation 
could go hand in hand with a reduction in the creation of relevant knowledge and a homogenisation of scientific production. As it stimulates quantity and prioritises the publication of papers in scientific journals over books, the result could be a disciplinary institutionalisation that produces ultra-specialised results of limited scope, to the detriment of long-term research and the construction of "great theories" and inclusive explanations (BRANDÃO, 2007).

A significant part of these criticisms can be attributed to a lack of information about the parameters traditionally employed in the process of academic assessment responsible for disciplinary institutionalisation. If "institutionalisation" can be understood as the constitution of a field with its own rules, values and hierarchies, the institutionalisation of Political Science as a discipline means that the values that determine its recognition and professional status do not result from the approval of entities such as "public opinion" (in the shape of social popularity) or from a deference typical of other social categories such as Law, Journalism or Literature and their valuing of rhetoric, proselytism or essayism. Rather, they derive from codes and parameters pertaining to a treatment of "politics as science" (BARRY, 1996; SARTORI, 1984; SKINNER, 1978; VON BEYME, 1996).

Contrary to what the critics say, it is precisely quality that the institutional assessment of the postgraduate system values, minimising the importance of the quantity of scientific production. This is evident in the creation of the Qualis system, responsible for rating the quality of scientific publications based on criteria pertaining to each field of study, but with peer recognition in common. Peer recognition is expressed by the impact factor, calculated by the number of citations (that is, the importance that academic peers attribute to a certain author's contribution), the rigour and selectivity in the peer review procedures adopted by each periodical for accepting articles, or even more subjective criteria such as the importance attributed to a journal in a certain disciplinary field. For evaluating the institutional performance of Brazilian postgraduate degrees, the production of few articles published in periodicals classified as being in the upper categories of the Qualis system (and therefore with a greater potential for citation, rigour in accepting work or recognition in the disciplinary community) is more valued than a great quantity published in periodicals classified as being in the lower categories. 
In this way, quality - gauged by different procedures for measuring the judgement and recognition of peers - takes unequivocal precedence over the amount of scientific publications in the academic assessment and institutionalisation ${ }^{2}$.

The assumption that greater academic institutionalisation should go hand in hand with theoretical and methodological homogenisation seems equally devoid of evidence. Based on a comparison between journals ranked in the upper Qualis/Capes categories and between different analytical schools and thematic areas, Leite and Codato (2013) concluded that:

We have three extremes. In one of them, there is Lua Nova, closer to political theory, concept analysis and history of ideas (TP-HI). In another, Opinião Pública, closer to values, attitudes, participation and politics (VAP-P). In the last one, the Brazilian Political Science Review, closer to the performance of political institutions (DIP). In addition, there seem to be two other clear positions: Dados also shows a pull towards DIP, and the Revista de Sociologia e Política and the Revista Brasileira de Ciências Sociais (to a lesser degree) are closer to the State, society and government policies area (ES-PG) ${ }^{3}$. These two periodical make up the centre (LEITE and CODATO, 2013, p.19).

The scenario presented by Leite and Codato (2013) suggests that institutionalisation and theoretical and methodological pluralism co-exist side by side. That is, the creation of a values hierarchy for the scientific periodicals of the area of Political Science did not signify the hegemony of one analytical school, but, on the contrary, ensured that there was space in the higher classification categories for publications of a neo-institutionalist, behaviourist, political sociology, normative theory or Marxist nature, among others.

Finally, a relevant question regarding "productivism" is the importance attributed by the institutional assessment to the process of internationalisation of scientific production. Here, the question directly concerns the parameters of quality expected from activities of knowledge production and academic research. Indicators that the expected requirements of quality, as well as of originality,

\footnotetext{
2 See the Document of the Area of Political Science and International Relations at http://www.capes.gov.br/images/stories/download/avaliacaotrienal/Docs_de_area/CI\% C3\%AAncia_Pol\%C3\%ADtica_doc_area_e_comiss\%C3\%A3o_21out.pdf.

${ }^{3}$ Abbreviations of the Portuguese terms for the themes of the Area of Political Science used by the Qualis/Capes system (translator's note).
} 
relevance and creativity were attained can be identified when the results of academic research have repercussions, are recognised and used in the form of citations - not only within Brazil's disciplinary community, but increasingly among international peers.

The second question concerns the relationship between institutionalisation and the production of specialised knowledge and knowledge of "medium reach", in contrast with the great interpretative models by the previous generation of Brazilian "social thought".

Arguing in favour of a progressive/cumulative interpretation of the history of Political Science, Almond (1996, p. 51) suggests that the development of notions such as "justice" and "democracy" could not have happened without the contributions of Plato and Aristotle. However, he recalls that today's knowledge of theories of justice cannot fail to consider the refinement and rigour included in treatments such as those by Walzer and Rawls, in the same way that Dahl and the neo-institutionalists furthered our knowledge on the "nuts and bolts" of today's democratic institutions. In this sense, it seems pointless to stretch the gap between the generation of the "interpreters" and that of the "professionals", centred on an institutionalised postgraduate system. If a concept such as "bureaucratic stratum" was vital to bring the State back into the focus of analyses on Brazil's social and political formation, recent contributions from postgraduate laboratories allowed knowledge on how Brazil is governed to be furthered, thus generating important information on intergovernmental relations, the makeup of governmental bureaucracies, the formation of public policy agendas, federalism, the voting decision and party organisation. In the light of criticisms such as those outlined by Carvalho (1980, p.38) and Schwartzman (1982, p. 60) of the notion of "bureaucratic stratum", would it be credible to state that the knowledge generated in the last four decades of institutionalised postgraduate programmes has added little to an understanding of the agents and mechanisms that configure the institutional dynamics of Brazilian politics?

\section{Professionalisation and institutional spaces for research}

An initial step for analysing disciplinary institutionalisation is to consider the chronological differences between the founding of different scientific 
associations. In Political Science, the establishing of scientific associations is part of a trajectory of growing disciplinary specialisation and autonomy, with a demarcation of the field in relation to Philosophy, Law and, later, Sociology (ALMOND, 1996; DOGAN, 1996; GOODIN, 2009; GOODIN and KLINGEMANN, 1996). Thus, outside of Brazil, there was no time lag between the creation of Political Science associations and those of the other traditional areas of the social sciences. In the United States, the founding of the American Anthropological Association (1902), the American Political Science Association (1903) and, shortly after, the American Sociological Association (1905) was virtually simultaneous. In France, even in a context of slow dissociation between Political Science and Sociology (FAVRE, 1985; FAVRE and LEGAVRE, 1998; GRAWITZ and LECA, 1985), the Association Française de Science Politique was created as early as 1949, before the Societé Française de Sociologie (1962) and its successor, the Association Française de Sociologie, created only in 2002. Although the founding of the Sociedad Argentina de Análisis Político in 1982 was late compared to that of the Sociedad Argentina de Antropología (1936), it still happened much earlier than that of the Asociación Argentina de Sociología, whose creation dates only from 20094. In Chile, the Asociación Chilena de Ciencia Política originated in 1966, with a hiatus after the authoritarian regime was implemented, resuming in 1983. In contrast, the $8^{\text {th }}$ Chilean Sociology Congress, in 2014, was held by the Sociology Network of Chilean Universities (Red de Sociología de las Universidades Chilenas), given the lack of a professional association for the discipline. As for the international associations of these disciplines, there was some synchrony between them: both the International Political Science Association (IPSA) and the International Sociological Association (ISA) were created in 1949.

Rather suggestively, there was a hiatus in Brazil that separated, on one side, the founding of the Sociology and Anthropology associations and, on the other, those of political scientists. While the Sociedade Brasileira de Sociologia was created in 1948, holding its first congress six years later, in 1954, and the Associação Brasileira de Antropologia dates from 1955, having held its first congress two years previously, three decades elapsed before the Associação

See Estatutos, Asociación Argentina de Sociología at http://aasociologia.globered.com/categoria.asp?idcat=47. 
Brasileira de Ciência Política came into existence in 1986, and yet another decade before it held its first congress in 1996, on the premises of Cândido Mendes University.

Although scientific associations are important for constituting a disciplinary community and setting common research agendas, the strongest driving force for the professionalisation of academic work is probably the expansion of academic institutions, which is also a platform for the institutionalisation of each area of knowledge. Assessment systems, researcher training, professional recruitment and infrastructure for scientific research are some of the by-products of the academic system, responsible for promoting treatment models for political objects different from the essayism and dilettantism seen in political commentators, journalists, jurists, etc. One of the paradoxes of the Brazilian authoritarian regime was that not only did it not destroy higher education as the military did in countries such as Argentina but, on the contrary, it expanded it, especially the postgraduate system and agencies of scientific and technological development (TRINDADE, 2007). However, Political Science arrived late at Brazilian universities. According to a survey carried out by Tavares de Almeida (2005), by 2003 there were only five Political Science undergraduate courses in the country, compared to a total of 64 Social Sciences and 43 International Relations courses in the same year. Although social sciences courses are usually a sort of a cluster of Anthropology, Political Science and Sociology, the same study by Tavares de Almeida revealed that the presence of Political Science in this context is a rather modest one: in 39\% of the Social Sciences bachelor's degrees there was not a single Political Science subject. $44 \%$ had up to eight subjects, and only in $17 \%$ of them did Tavares de Almeida identify a more significant presence, with an offer of more than eight subjects.

There have been significant changes in the last decade - especially after the Reuni Programme of expansion of federal universities -, with an increase in the number of International Relations undergraduate courses, and more recently, Public Policy courses (PIRES et al., 2014). USP, UFRGS and UFABC were some of the higher education institutions that started offering these undergraduate degrees. According to the Higher Education Census, in 2011 there were 179 undergraduate courses aimed at training students in Public Management or Public 
Policy. Out of all of them, 82 (46\%) were in Public Management, 46 (26\%) were in Public Administration, 16 (9\%) were in Public Security Management, 15 (8\%) in the area of Health, 13 (7\%) in the area of Social Management, 5 (3\%) in Public Policy Management and two (1\%) in Public Policy. Out of the total number of courses, 101 (56\%) were technical and 67 (37\%) were bachelor's degrees, with 105 (59\%) created in the last year. Although this scenario has shown some improvement in the last decade, in a great many number of cases these degrees were led by professionals from areas such as History, Law and Business Management, reproducing the marginal presence of political scientists in the training of human resources in Brazilian universities.

A more nuanced panorama of the development of Political Science in Brazil can be seen when we shift the focus of observation to postgraduate programmes. The dynamics of postgraduate courses is a more adequate measure of the behaviour of scientific communities, whether because (a) at this level, the processes of specialisation and differentiation have been previously set off by the creation of programmes from each one of the social sciences areas; (b) because of their very nature, which is more closely linked to scientific investigation and the training of researchers, or lastly; (c) because the causality between the expansion of undergraduate and postgraduate degrees does not necessarily mean that a rise in undergraduate degrees is a condition for a rise in demand for MA and PhD courses, but rather, the offer generated by the training of masters, and especially doctors, feeds a demand for professional inclusion from the centre to the periphery of the system, pressing for greater differentiation, specialisation and the creation of new postgraduate programmes.

Political Science postgraduate degrees in Brazil had their founding moment in 1969, with the creation of the Master's in Political Science at UFMG ${ }^{5}$

${ }^{5}$ List of Brazilian Higher Education Institutions: CEBELA - Brazilian Centre for Latin
American Studies, FUFPI - Federal University of Piauí Federation, IUPERJ - University
Research Institute of Rio de Janeiro, IESP - Institute of Social and Political Studies, PUC-MG
- Pontifical Catholic University of Minas Gerais, PUC-RJ - Pontifical Catholic University of
Rio de Janeiro, UCAM - Cândido Mendes University, UEM - State University of Maringá,
UEPB - State University of Paraíba, UERJ-RI - State University of Rio de Janeiro -
International Relations, UFABC - University of the ABC Region, UFF-CP - University of the
State of Rio de Janeiro - Political Science, UFF-EE - University of the State of Rio de Janeiro
- School of Engineering, UFG - Federal University of Goiás, UFMG - Federal University of
Minas Gerais, UFPA - Federal University of Pará, UFPE - Federal University of 
and Political Science and Sociology at the former IUPERJ. Following that, an MA was created at UFRGS (1973). In the following year, an MA and the first PhD in Political Science in the country were created at the University of São Paulo, as well as an MA at Unicamp. However, the rate of creation of postgraduate courses was slow and the second doctorate (IUPERJ) only began in 1980. Another 16 years passed before the creation of a third one at UFRGS in 1996. 30 years after the "inauguration" of the Political Science postgraduate degree, there were only three programmes for training doctors. For MA courses, the rate was not much different, and the 10-course threshold was surpassed only in 1994. Throughout all of the following decade, only four new courses were added to the ones in existence, while the doctorates doubled from three to six.

An important inflexion in the patterns of expansion of the Political Science and International Relations postgraduate degrees can be seen from 2007. The growth curve of the MA courses shows a significant increase from that year onwards, propelled by the professional MAs and academic MAs in the Northeast, North and Centre-West. Out of the 21 new MA programmes approved between 2007 and 2013, 15 (71\%) were professional or created by the institutes of higher education of the North, Northeast or Centre West. On the other hand, the expansion of the offer of PhDs in Political Science and International Relations seems not to have had enough momentum to keep up with the demand generated by these "new frontiers", whether territorial or professional, having remained stable in the last few years.

\footnotetext{
Pernambuco, UFPEL - Federal University of Pelotas, UFPI - University of Piauí, UFPR Federal University of Paraná, UFRB - Federal University of Recôncavo da Bahia, UFRGS Federal University of Rio Grande do Sul, UFRGS-EE - Federal University of Rio Grande do Sul - School of Engineering, UFRJ - Federal University of Rio de Janeiro, UFSC - Federal University of Santa Catarina, UFSCAR - Federal University of São Carlos, UNB-CP University of Brasília - Political Science, UNB-RI - University of Brasília - International Relations, UNESP - University of the State of São Paulo, Unicamp - University of Campinas, Unieuro - Unieuro University Centre, UNIFA - University of the Air Force, USP - University of São Paulo (translator's note).
} 
Graph 01. The expansion of Political Science - MA and PHD programmes in Brazil

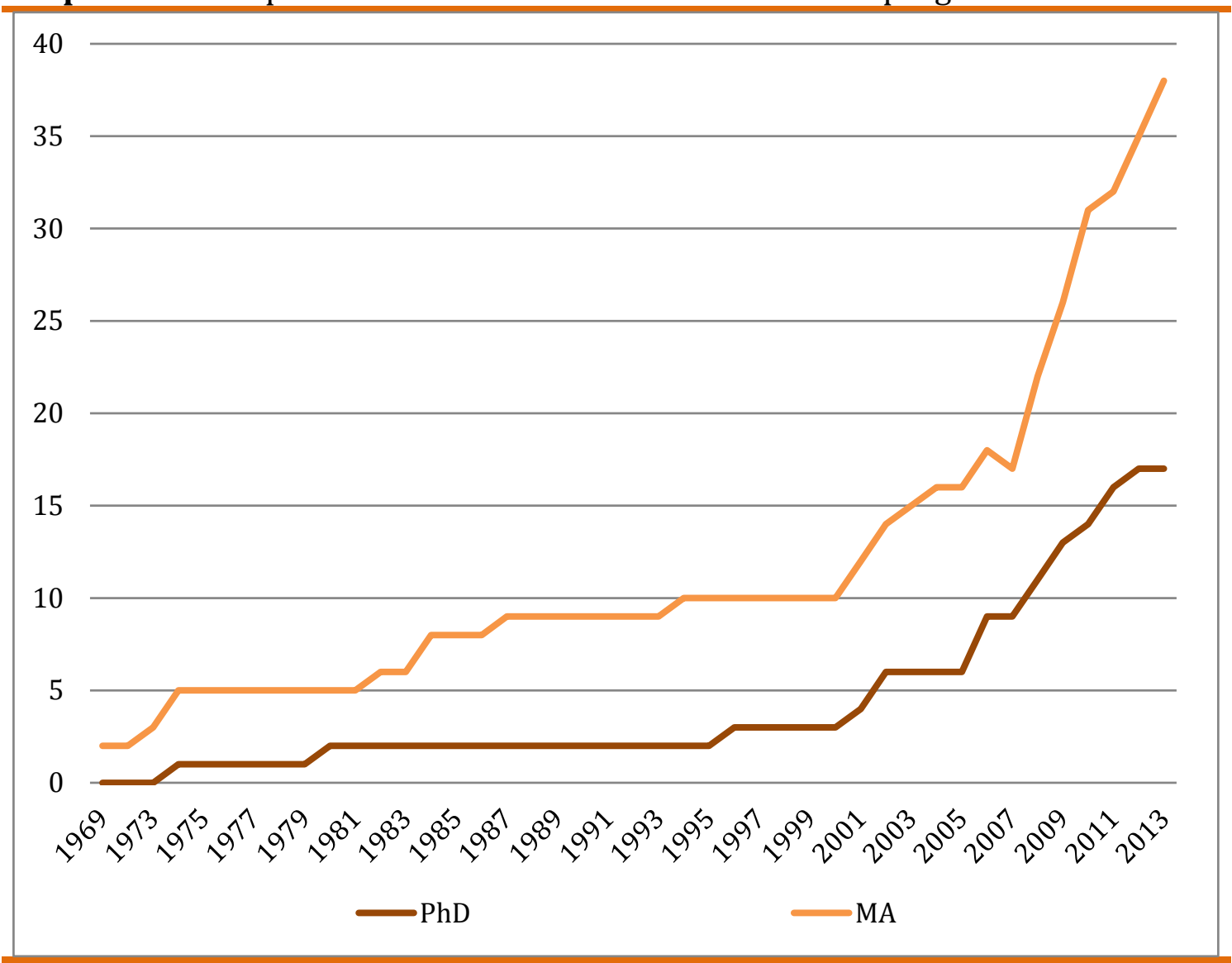

Source: Capes

If up until now the expansion of the postgraduate system by means of MA and $\mathrm{PhD}$ courses was the measure used to evaluate the institutionalisation of Political Science in Brazil, a more precise representation for analysing this process is to consider only the offer of $\mathrm{PhD}$ courses. The training of doctors is an inflexion in the postgraduate system, indicating a degree of institutional and scientific maturity achieved after years of experience in implementing academic MA programmes. The presence of PhDs in a scientific area shows that, the experience of the offer of courses concentrating on basic and general postgraduate training having been consolidated, academic institutions reached a higher level of scientific production and research, maturity of teaching staff and training of human resources, with significant advances in the professionalisation of academic activity. Therefore, if implementing PhD courses is an appropriate indicator for identifying the degree of institutionalisation of a field of study, what might a time series of the number of Political Science PhDs indicate? In other words, the question at this stage is whether the moderate expansion curve of PhDs is a phenomenon common 
to other areas of knowledge or the neighbouring Social Science disciplines ${ }^{6}$, or a peculiarity of the development of Brazilian Political Science. Graph 2, below, presents information that could provide a clue to answering this question.

Graph 02. The expansion of social sciences PhDs in Brazil - 1971-2013

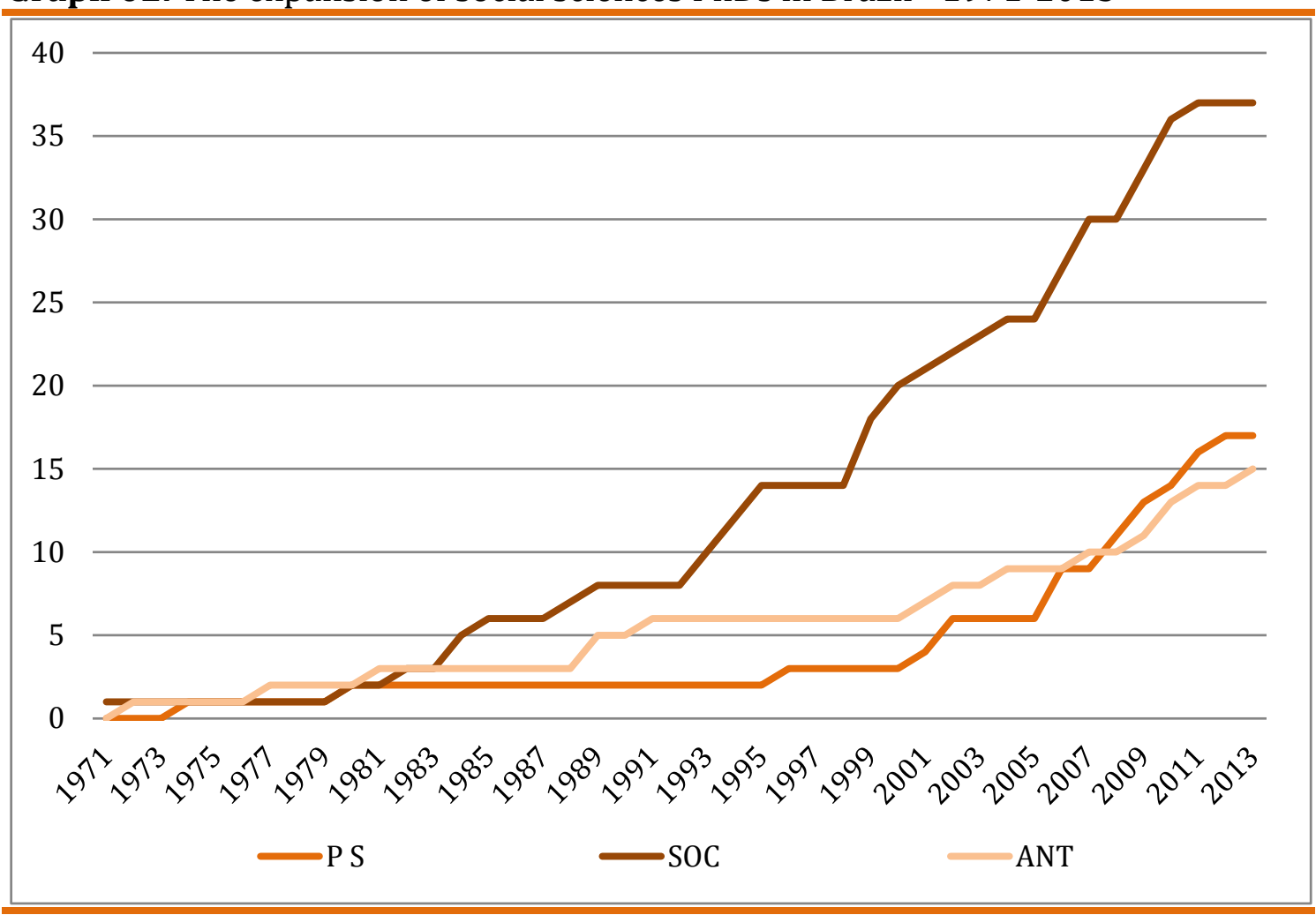

Source: Capes

Until the beginning of the 1980s, there was a similar number of $\mathrm{PhD}$ programmes in Political Science, Sociology and Anthropology. As well as the two Political Science PhD programmes at USP and IUPERJ, there were two in Sociology

\footnotetext{
${ }^{6}$ Here, we chose to maximise the similarities between the compared disciplines or cases, attempting to indicate the different patterns between them. Although the inclusion of cases/disciplines such as Economics, Law or Education could provide useful information, it would mean making a different comparative design, maximising the differences among cases in order to highlight the similarities between them. In Brazil, Political Science, Sociology and Anthropology have had a common trajectory, proven by academic ties such as, for example, the Associação Nacional de Pesquisa e Pós-Graduação em Ciências Sociais (ANPOCS - National Association for Research and Postgraduate Studies in Social Sciences), undergraduate courses in Social Sciences and in the majority of higher education institutions and postgraduate programmes starting at similar points in time. Although outside Brazil Political Science is very close to subjects such as Economics and Law, in Brazil, the latter have had origins and trajectories more distant from Political Science, which would considerably increase the heterogeneity and degrees of difference in a sample including them.
} 
(USP and IUPERJ) and two in Anthropology (USP and UFRJ). However, 16 years later, when the third Political Science PhD programme had only just been created (at UFRGS), Anthropology already had six PhD programmes and Sociology had 14. By 2004, the offer in Political Science had doubled to six, while Anthropology had reached nine and Sociology 24. If the rate of creation of new $\mathrm{PhD}$ courses in Political Science was enough to surpass Anthropology in 2008, it was still far from surpassing or even from being on a par with Sociology. Paradoxically, this is a phenomenon that goes against the principle of incremental returns suggested by the historical institutionalists, according to whom there are high costs to reversing the conditions present at the origin of social institutions. In this case, it is the contrary - although they started from a similar level, an inflexion occurred at an intermediate stage in the trajectory of each one of the areas, causing differences not in existence at the point of departure.

Another angle from which to analyse information on the expansion of postgraduate institutions is the territorial distribution of doctorates in the three areas (Graph 3).

Graph 03. States with $\mathrm{PhD}$ programmes

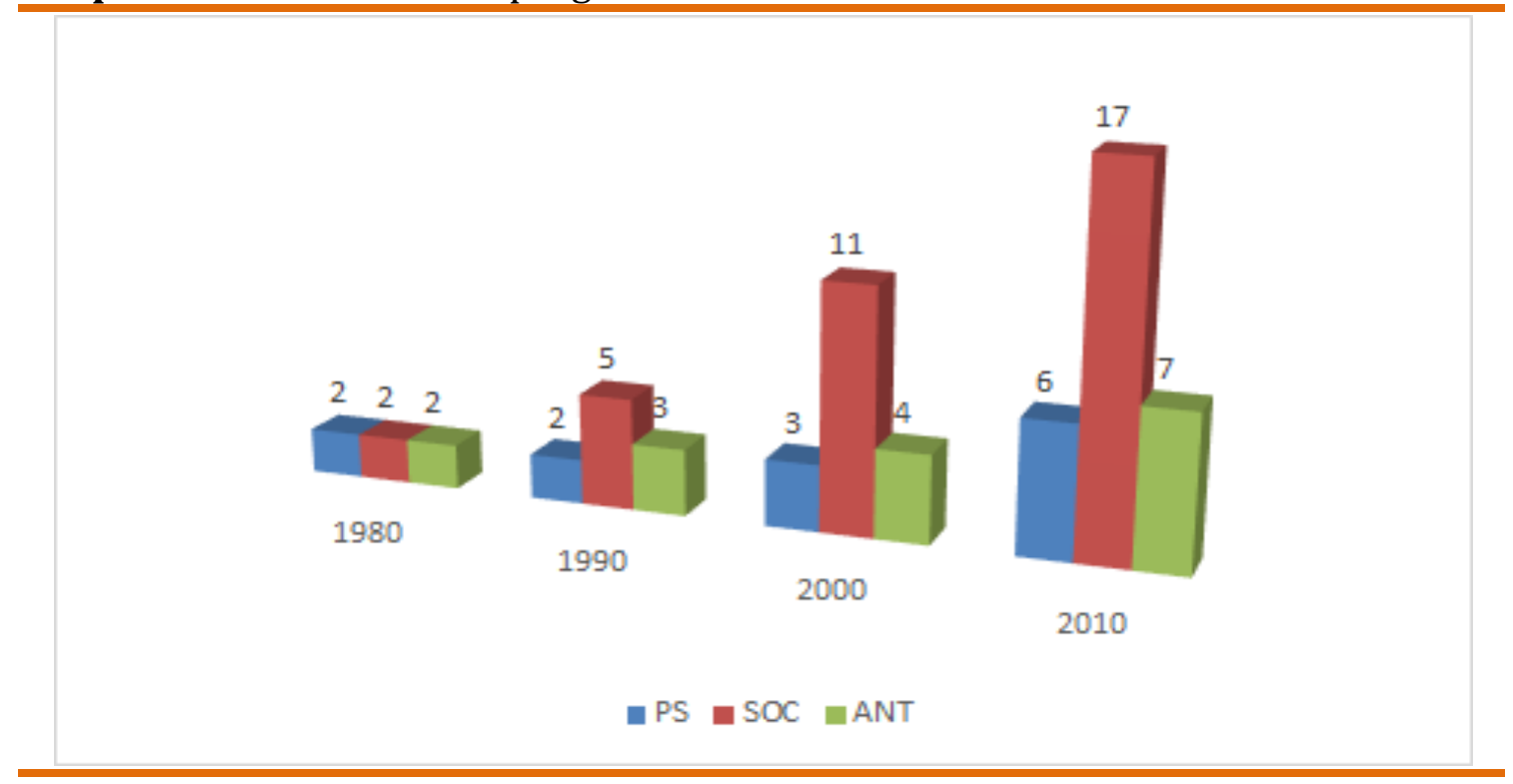

Source: Capes

In 1980, there were doctorates in all three areas in two Brazilian states, São Paulo and Rio de Janeiro. 20 years later, there was a Political Science PhD in another state (Rio Grande do Sul), while Sociology was already training doctors in 
11 states. 30 years later (or 41, considering the year of creation of its first MA programme), Political Science had doctorates in six states (São Paulo, Rio de Janeiro, Rio Grande do Sul, Minas Gerais, Pernambuco and the Federal District), which meant fewer that $1 / 4$ of the Brazilian states, and none in the Northern region. Meanwhile, Sociology, which had been at a similar level to the other areas, attained national reach with doctorates in 17 states in all of the Brazilian regions.

This analysis has hitherto considered only the offer of doctorate courses and its spread throughout the Brazilian territory through its presence in different states. This informs us as to the "installed capacity" to train high-level professionals in scientific research, but does not allow us to draw conclusions on the actual qualification rates. That is, on the capacity of the Political Science and International Relations programmes to train doctors. The graph below allows an initial approximation to be made by considering the $\mathrm{PhD}$ qualification rates in three areas (Political Science, Sociology and Anthropology), as well as averages for the entirety of the Brazilian postgraduate system. As the areas have different proportions (number of programmes and teaching staff), it does not make sense to present absolute numbers. Therefore, we considered the number of qualified doctors per capita, that is, the relationship between the number of qualified doctors every year and the number of permanent teaching staff in the postgraduate programmes in each area/year. The resulting information can be seen below, in Graph 4.

At the beginning of the period analysed, the number of doctors trained per permanent lecturer in PS and IR was at a low level (0.11), showing there was little less than one thesis defended per year for every 10 permanent scholars. At that point, in Sociology, the rate (0.39) was one thesis for every 2.6 scholars, while the behaviour of Anthropology was similar to the system's average performance. It is likely that the scarce availability of doctorates in PS or IR at that point may have contributed to this poor performance. As we move towards the end of the period, the trends are inverted: Sociology and Anthropology keep up with the average trend of decreasing productivity in the training of doctors, while in the area of PS and IR a significant increase is registered, practically doubling the doctors/permanent staff ratio, reaching a rate of 0.21 (or one thesis per every five 
permanent staff members), drawing with Anthropology and practically catching up with the average behaviour of the Brazilian postgraduate system.

Graph 04. PhDs per capita - 2004-2012

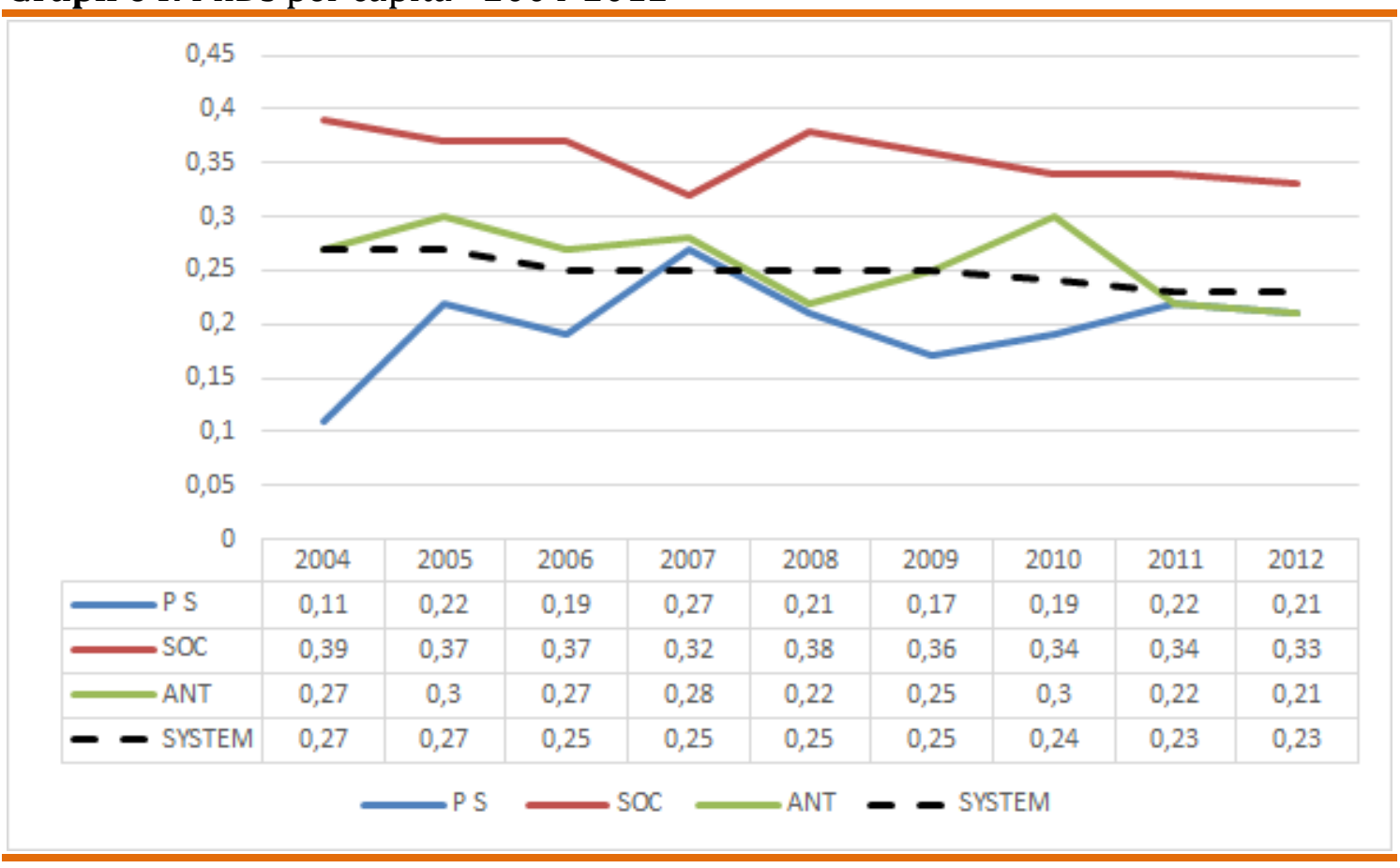

Source: Capes

An adequate measure for considering the degree of institutional consolidation of the areas and postgraduate programmes is obtained when the relationship between the number of doctors and masters trained in these institutions is compared. It is expected that the initial stages of implementation of a field of study or its postgraduate programmes will be characterised by a concentration in Master's degrees aimed at filling in the gaps in the training given by undergraduate programmes, and will offer an initial experience of applied research. An institutional inflexion can be observed when the centre of gravity of areas or institutions shifts to $\mathrm{PhD}$ courses. The repercussions of this are a strengthening of the ability to carry out research and scientific production, a systematic engagement of students in academic research and publishing projects and a less generalising education, more oriented towards the specialities resulting from differentiations within the discipline. Graph 5 shows a time series of the number of theses to dissertations recorded in the areas of Political Science (ps), Sociology (soc) and Anthropology (ant), as well as information on the average of the Brazilian postgraduate system. 
Graph 05. Theses/dissertations ratio by area - 1998-2012

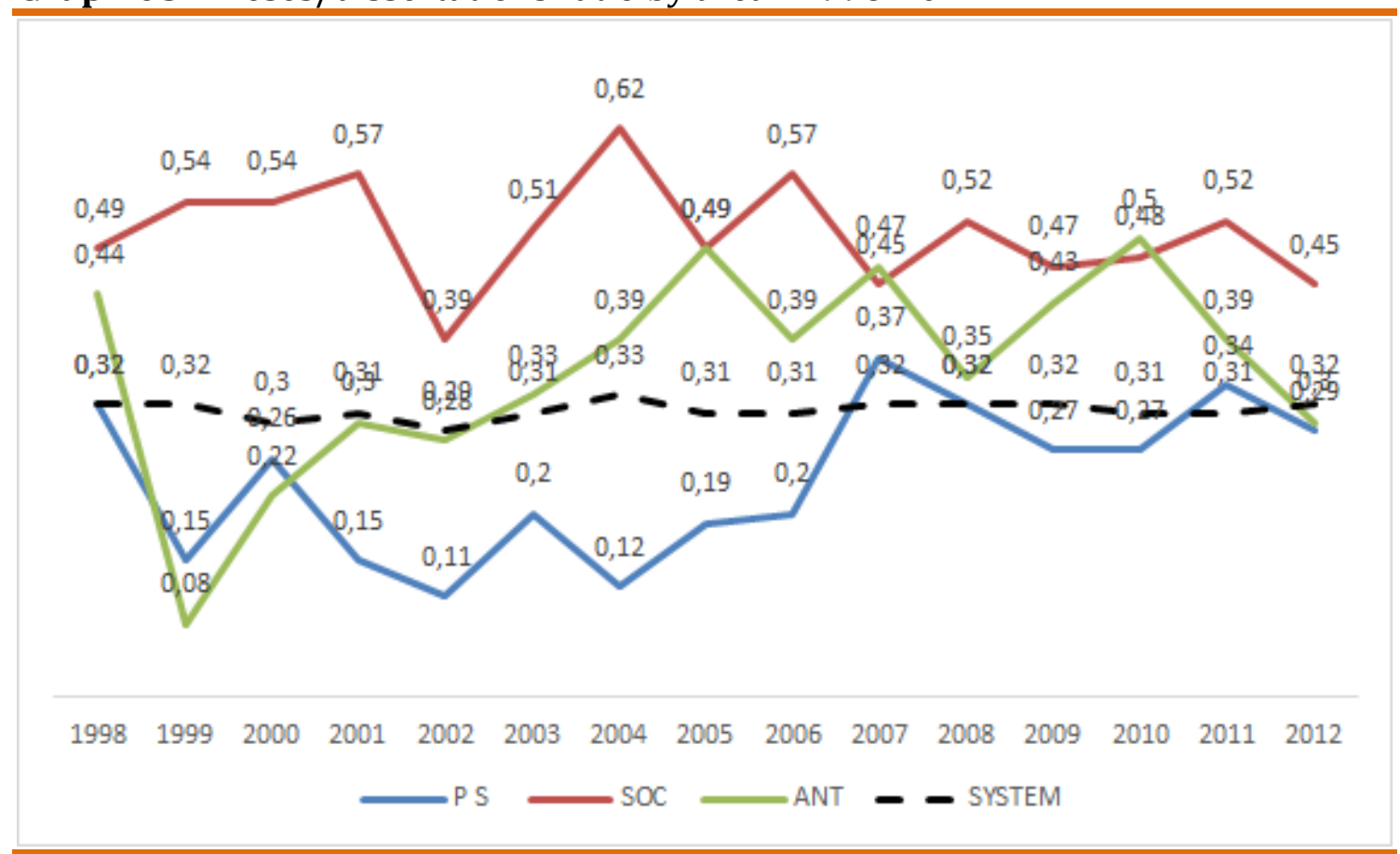

Source: Capes

Until 2006, qualifications in the area of Political Science and International Relations followed a pattern of one thesis to five dissertations. In the same period, Anthropology came close to one thesis to two dissertations, a level that Sociology had already stabilised at since the end of the 1990s. Considering that the minimum period for a thesis to be concluded is four years, this means that until then only three PhD courses had succeeded in qualifying new doctors in Political Science. After 2007, and probably as a result of the first few groups graduating from the new PS and IR PhD courses created in the first half of the decade, we see a slight improvement, with close to one thesis for every three dissertations defended. By way of comparison, in the 2010-2012 period, in areas such as Astronomy \& Physics and Biological Sciences III the ratios of PhDs to Masters' qualified were 0.52 and 0.58 respectively. Finally, it could be argued that differences in course duration two years for a Master's degree and four years for a PhD - mean different proportions of student numbers in each of the levels, thus contributing to keep the differences in the number of masters to doctors. If this is correct, it should not subsume the importance of the institutional policy adopted in each 
programme/area in order to balance out the admission of MA and PhD candidates and attain greater efficacy in training doctors.

Following on from this point - a slower expansion of PS and IR PhD courses and a delay in the transference of the centre of gravity of postgraduate programmes from MAs to $\mathrm{PhDs}$-, the next question concerns the institutions responsible for training the teaching and research staff that make up the programmes at present. In order to assess this, the makeup of the teaching staff of the 32 programmes from the area of Political Science and International Relations included in the triennial assessment of 2013 was examined. The data was extracted from the Capes Report 2012, reflecting the makeup of the teaching body for that year.

The information was systematised into four categories: "home institution", signifying an endogenous pattern of recruitment, where the lecturer qualified in the programme where he/she is currently employed; "Political Science/Brazil" (PS/BR), signifying a pattern of institutional or geographical mobility, with the lecturer having been trained in a Political Science programme other than the one where he/she was employed in 2012; "Other Area/Brazil" (oth/BR), where the lecturer qualified as a $\mathrm{PhD}$ in Brazil, but in programmes pertaining to areas of knowledge other than Political Science; and lastly, "abroad", which means a PhD obtained in institutions outside Brazil.

The results, which consider the aggregate behaviour in the Area of Political Science, as well as the distributions verified in each programme, can be seen in Table 1.

The first observation to be made is that endogeny was a relatively low behaviour in the PS and IR programmes - only $7.2 \%$ of permanent teaching staff had qualified in the programmes in which they were employed in 2012. Interestingly, a greater frequency of endogenous recruitment was found precisely in the old, consolidated programmes (USP, UFMG and UFRGS), where their role as protagonists in training and supplying doctors of Political Science influenced the absorption of graduates into their own vacancies. In other words, in a context of fewer possibilities of doctorates abroad (1990s and early 2000s), fewer doctorates in the area in Brazil and little space for doctors from other areas entering into 
traditional and hard-core programmes such as these, there might have been no other alternative but to seek out new researchers from their own graduates.

Table 01. Origin of PhD qualification - permanent staff in PS and IR - 2012

\begin{tabular}{lccccc}
\hline Programme & Home institution & PS/BR & Oth/BR & Abroad & Year of creation \\
\hline AREA PS\&IR & 7.2 & 27.4 & 48.1 & 17.2 & \\
UCAM & 22.2 & 11.1 & 22.2 & 44.4 & 1969 \\
UFMG & 38.5 & 30.8 & 15.4 & 15.4 & 1969 \\
UFRGS & 25 & 25 & 18.7 & 31.2 & 1973 \\
USP & 70.6 & & 23.5 & $5.9^{*}$ & 1974 \\
UNICAMP & 6.7 & 20 & 60 & 13.3 & 1974 \\
UFPE & 16.6 & 25 & 16.6 & 41.7 & 1982 \\
UNB-RI & & 26.7 & 33.3 & 40 & 1984 \\
UNB-CP & & 7.1 & 14.2 & 78.6 & 1984 \\
PUC-RJ & 5.5 & 38.9 & 55.5 & & 1987 \\
UFF-CP & & 53.8 & 30.8 & 15.3 & 1994 \\
UNESP & & 40 & 60 & & 2004 \\
UNIEURO & & & 92.3 & 7.7 & 2006 \\
CEBELA & & & 100 & & 2006 \\
PUC-MG & & 54.5 & 18.2 & 18.2 & 2007 \\
UFSCAR & 9.1 & 38.5 & 46.1 & 7.7 & 2008 \\
UFPA & 7.7 & 66.6 & 22.2 & 11.1 & 2008 \\
UFPI & & 87.5 & 12.5 & & 2008 \\
UFF-EE & & 28.6 & 57.1 & 14.3 & 2008 \\
UEPB & & 62.2 & 66.6 & 11.1 & 2008 \\
UFPR & 40 & 60 & & 2009 \\
USP-RI & & 46.7 & 40 & 13.3 & 2009 \\
UFRJ & & 15.4 & 76.9 & 7.7 & 2009 \\
UERJ-RI & & 27.3 & 45.4 & 27.3 & 2009 \\
IESP & & 50 & & 50 & 2010 \\
UFRGS-EE & & 6.1 & 69.2 & 7.7 & 2010 \\
UFPEL & & 30 & 10 & 2010 \\
UFRB & & 6.2 & 87.6 & 6.2 & 2010 \\
UEM & & 91.6 & 4.2 & 2010 \\
UFSC & & 61.1 & 27.8 & 2010 \\
UFG & & 94.1 & 28.6 & 2011 \\
UNIFA & & & & & 2012 \\
\hline SOurCe:Cape & & & &
\end{tabular}

Source: Capes Report, 2012

Note: There is a discrepancy in the data on USP staff members presented in the Capes Report and that extracted from the Lattes Platform. According to information from the Lattes Platform, the qualification of one of the lecturers from this institution was abroad, while the Capes Report says differently. In this case, we chose the information provided by the lecturer via the Lattes CV.

How should we interpret the presence of lecturers trained abroad? According to Altman(2012), the ability to recruit scholars with a PhD from institutions of international reputation, particularly US American ones, is an element to be considered when ranking the Political Science departments of Latin 
America. In other words, the presence of internationally qualified staff in itself might signify academic capital, making a distinction between institutions and Latin American countries. Not discounting the positive effect of training in the main international centres of excellence, this could be a bias and indicate the occurrence of a preliminary stage of institutional consolidation. A high density of qualifications obtained abroad could be seen in Brazilian Political Science programmes until the 1990s, and even more recently in Argentinian, Chilean and Uruguayan ones, basically indicating the dwindling number of PhD programmes offered in the countries mentioned. In contrast, it is expected that an expansion in the offer of programmes - especially if it is related to high-quality parameters - will be followed after a few years by a rise in the frequency of lecturers and researchers hired by their own or by other postgraduate programmes in the same country.

The pattern of institutional mobility, represented by the recruitment of staff with PhDs obtained in other programmes in Brazil, is a little over one to every four permanent lecturers in Brazil's Political Science programmes. This is more prominent in recently created programmes such as those of UFPA, UFG, FUFPI and UFPEL. That is, programmes in regions or mesoregions with a smaller institutional density of postgraduate programmes, which benefitted from the supply of doctors from the first few groups trained by the new PhD courses from the mid-2000s, or even, from specific actions such as the interinstitutional $\mathrm{PhD}$ programmes of Iuperj/UFPA and Unicamp/Fufpi. Using different data, Madeira(2013) identified a similar pattern. Note that this recruitment pattern based on institutional or geographical mobility is less frequent in the older, consolidated programmes, which seem to prefer renewing their staff by recruiting from abroad or from their own institutions ${ }^{7}$.

Finally, what is the meaning of the fact that $48.1 \%$ of permanent teaching staff employed in Political Science or International Relations programmes obtained their PhD qualifications in Brazil, but in courses and programmes other than Political Science and International Relations? This seems to be a significant trend in more recently created programmes, professional Masters' and some International Relations programmes. Among the programmes in existence for over

\footnotetext{
${ }^{7}$ The apparent contradiction of the $50 \%$ of IESP teaching staff originating from Brazilian PS programmes actually confirms this trend. This entire contingent comes from the former IUPERJ, whose link with today's IESP is well known.
} 
10 years, the average proportion of scholars trained in Brazil but in other areas of knowledge is $29 \%$. If we consider the more recently created programmes, in the last year, this proportion rose to 55.7\%. Parallel to that, out of the 21 programmes created in the last 10 years, eight were in International Relations, with a heterogeneous composition of teaching staff (History, Law and Economics, as well as Political Science), and six were in institutions of an interdisciplinary design. One possible interpretation for this phenomenon is the reduced offer of doctors in PS and RI, as a result of the delay in creating doctorates in the area until the mid2000s. Parallel to that, we can consider that the interdisciplinary nature of these courses drove the creation of courses with professionals qualified in History, Law and Sociology, who had previously and firmly been part of higher education institutions. As well as being a symptom of the precarious or delayed institutionalisation of Political Science in Brazil, we can speculate about the implications of this (both positive and negative) for the constitution of an academic community with its own agenda and parameters.

This first section has sought to demonstrate the delayed process of institutionalisation of Political Science in Brazil. The area's scientific association began its activities with a four decade delay compared to its correlates, Sociology and Anthropology. After beginning at a similar level, from the 1990s onwards there was a lag between the creation of postgraduate programmes in Political Science and Anthropology, but particularly between Political Science and Sociology. The more pronounced difference was in the offer of $\mathrm{PhD}$ courses, causing an undersized rate of $\mathrm{PhD}$ trainings. The consequence of this was a deficit of doctors, reflected particularly in the composition of staff of programmes created later.

\section{Institutionalisation as a way of constituting an assessment system}

A second dimension for examining the institutionalisation of a disciplinary field can be achieved by combining scientific research and qualified publication with an assessment of institutional performance based on peer judgment, as bases for constituting academic hierarchies and allocating resources for scientific investigation. Parallel to that, the integration of postgraduate and research groups into international networks and circles, and their visibility in the academic 
community, measured by means of impact indicators and citations, complement this process of academic institutionalisation. This section attempts to examine this dimension by considering the evolution of the scientific production of Political Science in Brazil and the institutional assessment carried out by Capes.

We can draw closer to an understanding of the identity of Political Science programmes when we aggregate the information on their lines of research. As the nomenclature of the lines of research varies greatly - with different names for the same content and specific lines side by side with combinations of thematic areas in one single line -, we chose to consider the lines of each of the programmes using a conventional grouping of thematic areas characteristic of the core of Political Science. These were the following: political theory, political culture, international politics, public policy, elections and parties, political institutions and society and participation. International Relations programmes were excluded, as it is not expected that IR programmes should have thematic lines associated with areas pertaining to PS - showing greater detail or specialisation within "International Relations" -, although they do use a thematic line titled "international politics".

Table 02.Thematic areas in the lines of research of Political Science programmes - 2012

\begin{tabular}{|c|c|c|c|c|c|c|c|}
\hline Programme & Theory & $\begin{array}{l}\text { Political } \\
\text { Culture }\end{array}$ & $\begin{array}{l}\text { Internatl } \\
\text { Politics }\end{array}$ & $\begin{array}{l}\text { Public } \\
\text { Policy }\end{array}$ & $\begin{array}{l}\text { Elections } \\
\text { and Parties }\end{array}$ & Institutions & $\begin{array}{l}\text { Society and } \\
\text { Participation }\end{array}$ \\
\hline \multicolumn{8}{|l|}{ USP } \\
\hline \multicolumn{8}{|l|}{ UFMG } \\
\hline \multicolumn{8}{|l|}{ UFPE } \\
\hline \multicolumn{8}{|l|}{ IESP } \\
\hline \multicolumn{8}{|l|}{ UFRGS } \\
\hline \multicolumn{8}{|l|}{ UNICAMP } \\
\hline \multicolumn{8}{|l|}{ UNB-CP } \\
\hline \multicolumn{8}{|l|}{ UFPR } \\
\hline \multicolumn{8}{|l|}{ UFF-CP } \\
\hline \multicolumn{8}{|l|}{ UFSCAR } \\
\hline \multicolumn{8}{|l|}{ UFG } \\
\hline \multicolumn{8}{|l|}{ UFPA } \\
\hline \multicolumn{8}{|l|}{ UFPI } \\
\hline \multicolumn{8}{|l|}{ UFPEL } \\
\hline \multicolumn{8}{|l|}{ UFRB } \\
\hline \multicolumn{8}{|l|}{ UEM } \\
\hline \multicolumn{8}{|l|}{ UNIEURO } \\
\hline UCAM & & & & & & & \\
\hline
\end{tabular}

Source: Capes Report, 2012 
A more advanced degree of institutional consolidation should translate into a more diversified teaching body, overcoming the thematic specialisation that goes with or propels a programme it in its initial stages. This does not mean that programmes do not have their own inclinations, with research results in areas in which they are stronger or more prolific, but a disposition towards a full thematic range, despite internal asymmetries in the productivity of each one of them. This trend is seen in older Programmes such as those of UFMG, USP, UFRGS, Unicamp, UNB and IESP, which show a range of themes in their research lines, including the discipline's entire research agenda, or almost all of it. In contrast, in more recent programmes, we see gaps in the lines of research, or even hyperspecialised programmes that show a line structure pertaining to a single thematic area.

Capes has carried out an assessment of Brazilian postgraduate programmes since 1976. This evaluation process involves two dimensions: (i) the accreditation of programmes and courses through the "Assessment of New Postgraduate Course Proposals" (APCN - Avaliação das Propostas de Cursos Novos de Pós-graduação), carried out annually and requiring minimum levels of quality for creating new programmes ${ }^{8}$; and (ii) the Triennial Assessment, when all the programmes recognised by the postgraduate system go through an assessment of their performance ${ }^{9}$ and are awarded a grade for indicators of scientific production, ability to train MAs and PhDs, degree of internationalisation, student publication and relevance for society ${ }^{10}$. Both the assessment of new courses and the triennial evaluation are (currently) carried out based on 48 Areas of Knowledge ${ }^{11}$, perform a preliminary analysis and issue opinions to the Technical-Scientific Higher Education Council (CTC-ES - Conselho Técnico Científico de Educação Superior),

\footnotetext{
${ }^{8}$ For the criteria used by the Area of Political Science and International Relations for analysing new course proposals, see the Area Document at http://www.capes.gov.br/images/stories/download/avaliacaotrienal/Docs_de_area/CI\% C3\%AAncia_Pol\%C3\%ADtica_doc_area_e_comiss\%C3\%A3o_21out.pdf.

9 For the general criteria used in the Triennial Evaluation 2013, see https://docs.google.com/viewer?a=v\&pid=sites\&srcid=Y2FwZXMuZ292LmJyfHRyaWVuY WwtMjAxM3xneDozODgxYTU2NTA1MzAyMjI3.

10 For the criteria adopted by the Area of Political Science and International Relations in the Triennial Evaluation 2013, see the Area Document at http://www.capes.gov.br/images/stories/download/avaliacaotrienal/Docs_de_area/CI\% C3\%AAncia_Pol\%C3\%ADtica_doc_area_e_comiss\%C3\%A3o_21out.pdf.

11 A list of the 48 Areas of Knowledge in operation in 2013 can be found at http://www.capes.gov.br/avaliacao/areas-paginas.
} 
which makes decisions regarding the parameters and criteria and grades attributed to the programmes ${ }^{12}$. The grades range from 1 to 7 , with 3 being the minimum grade for opening or keeping a course or programme, and 6 or 7 awarded to institutions with a performance akin to those of international centres of reference.

The core of the assessment carried out on the Brazilian postgraduate system can be whittled down to a combination of (i) scientific production - as a proxy for academic quality and vocation for research, (ii) the training of masters and doctors, but particularly doctors, and (iii) the degree of internationalisation obtained by each programme. According to the 2013 Triennial Evaluation Regulations, the maximum grade (7) must be awarded only to institutions with a "highly distinguished level of performance (in the training of doctors and intellectual production) in relation to other programmes in the area; and a performance equivalent to those of international centres of excellence in the field (internationalisation and leadership)"13. A high-level postgraduate programme is expected to display a strong capacity to train doctors. The quality required from this training is - indirectly - measured by the teaching body's vocation for research, confirmed by a high per capita frequency of publication in periodicals ranked in the upper Qualis categories and/or in highly rated books, of quality equivalent to that of the area's main international institutions.

For a programme to be awarded a grade 7 - the system's highest - its performance must be equivalent to that of international centres of excellence of its field. It must show highly distinguished indicators of scientific production compared to those of other programmes in the field, and the ability to train doctors and be awarded a "very good" grade in all the requirements and items of the evaluation ${ }^{14}$. It is therefore a reference point due to its degree of internationalisation and the recognition of its position of academic leadership within the international academic community.

12 Regarding the attributions and composition of the CTC-ES, see http://www.capes.gov.br/sobre-a-capes/ctc.

13 The Regulations for the Triennial Evaluation 2013 (2010-2012), p.7, can be found at https://docs.google.com/viewer?a=v\&pid=sites\&srcid=Y2FwZXMuZ292LmJyfHRyaWVuY WwtMjAxM3xneDozODgxYTU2NTA1MzAyMjI3.

${ }^{14}$ Capes. Regulations for the Triennial Evaluation 2013, p. 07. 
The evolution of grade 7 programmes in Political Science (ps), Sociology (soc) and Anthropology (ant) can be analysed in the Graph below:

Graph 06. Number of grade 07 programmes by area - 2001-2013

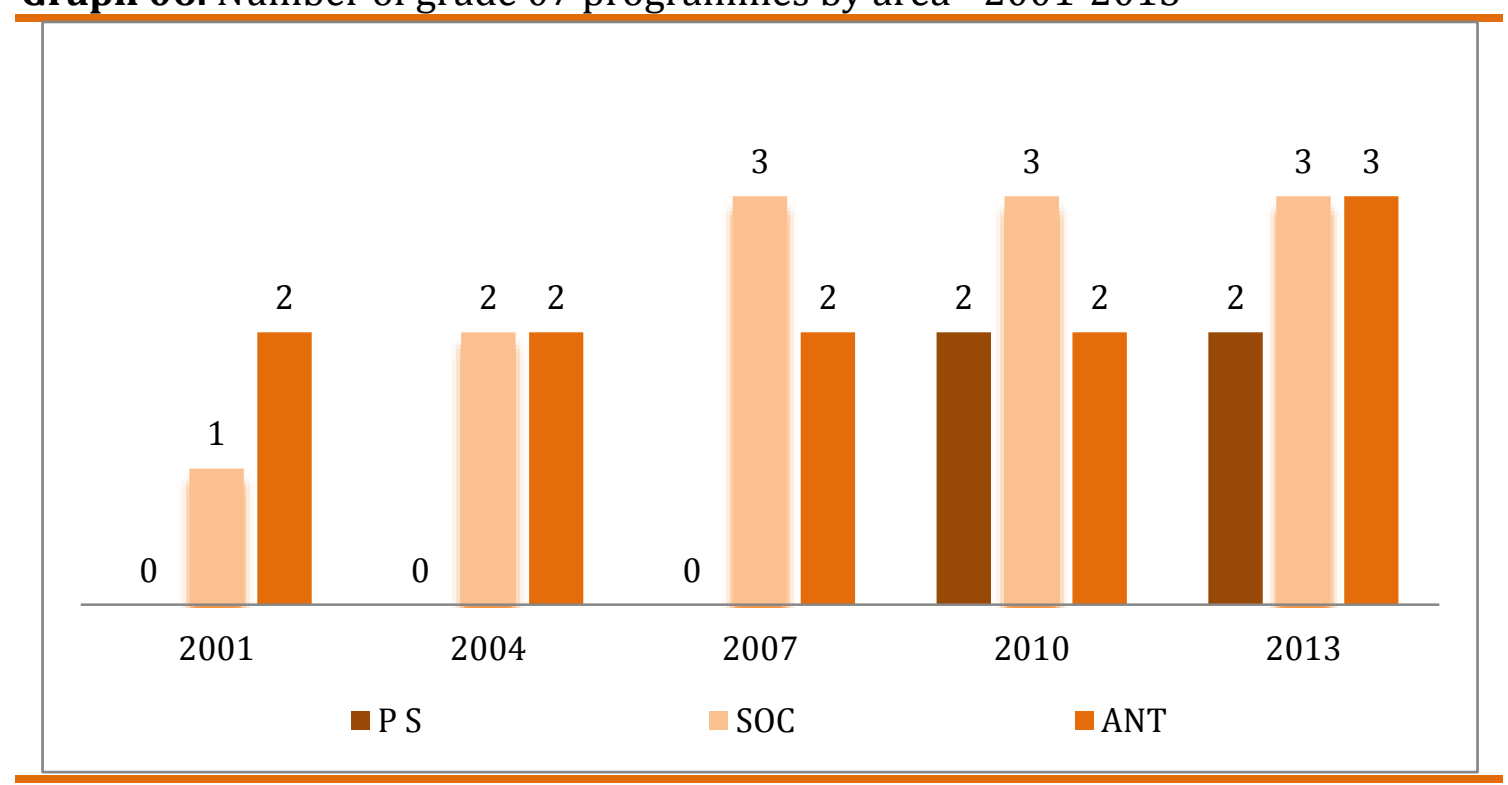

Source: Capes

The institutional mismatch between the area of PS and IR in relation to its neighbours can be measured by the fact that compared to Anthropology and Sociology, they took longer to be awarded their first maximum grades. While the latter were awarded one and two sevens respectively in the 2001 Triennial Evaluation, another three triennial periods elapsed before the first maximum grades were achieved by Political Science programmes (USP and IUPERJ) in 2010.

Although scientific publication is not the only factor for assessing the performance of postgraduate institutions, it is an adequate measure for considering the vocation for academic research and the international visibility of the production by Brazilian researchers. In order to rate the scientific production of the postgraduate programmes, periodicals are classified into one of eight categories (A1, A2, B1, B2, B3, B4, B5 and C) based on criteria that vary in each area: the impact factor, indexing, internationalisation and qualitative criteria. In the Political Science Area, only publications in periodicals classed as A1, A2 and B1 are considered when awarding points for scientific production. Among the requirements for the Area to consider a journal in these categories are the impact 
factor (for foreign periodicals), inclusion into the Scopus Bases (for A1 and A2) and in Scielo (for B1) ${ }^{15}$.

The evolution of the scientific production of PS and IR can be observed in the information presented in the graph below, which portrays the most internationalised publications in the highest category of Qualis (IA until 2007, A1 after 2010).

Graph 07. Production of quality per capita, PS \& IR - 2004-2013

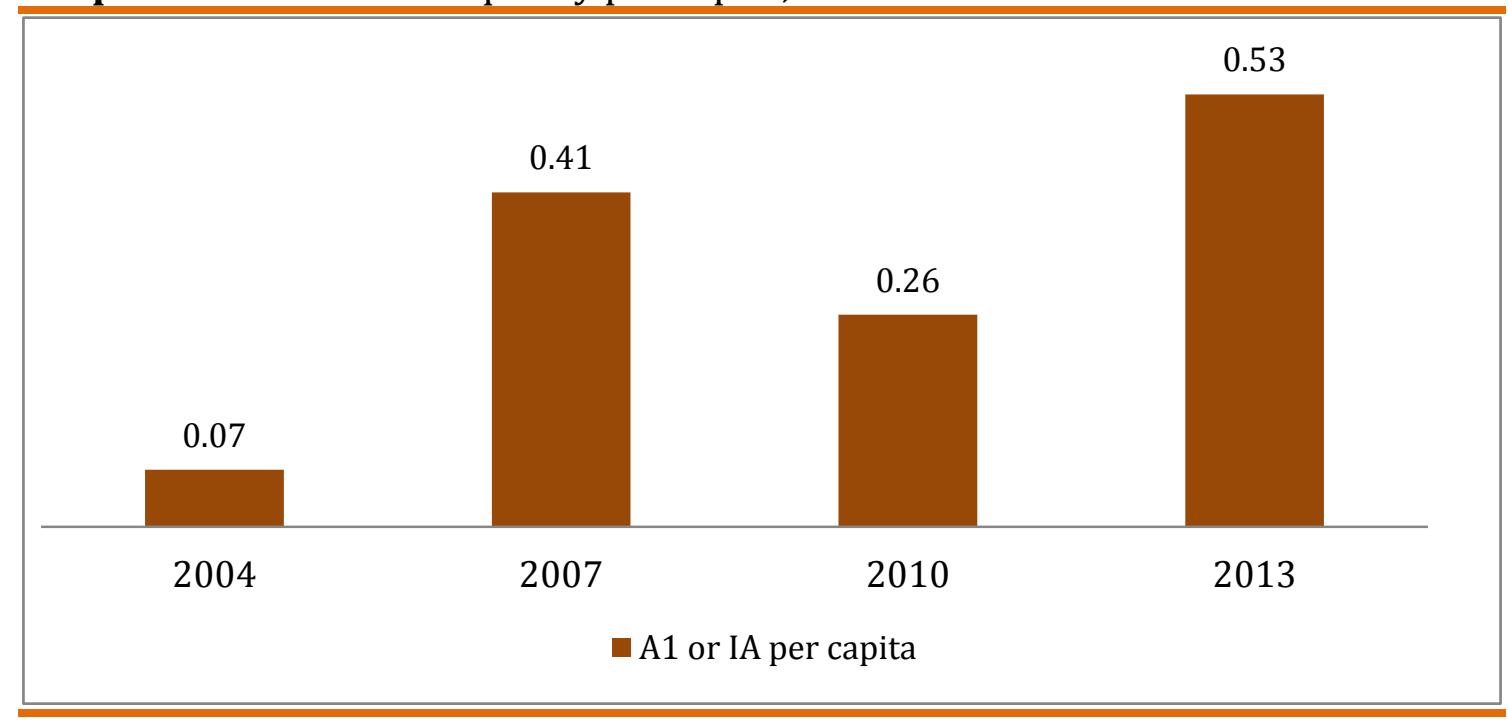

Source: Capes

A clear evolution can be observed in the per capita production of the highest category of the Qualis/Capes classification: 657\% between 2013 and 2014 and $103 \%$ when only the variation between the 2013 and 2010 triennial periods is considered. Journals classified in the A1 category represented $8.6 \%$ of the total periodicals in the Qualis/Political Science and International Relations classification in the $2007 / 2009$ triennial period. Their participation was reduced to $5.9 \%$ during the $2010 / 12$ triennial period, a $31.4 \%$ decrease in relative participation. In contrast, actual production increased by $103 \%$, showing that in spite of the greater selectivity suggested by the smaller offer of periodicals in the period, there was a real increase in production of greater quality. Whether this was due to the inductive effect caused by the Qualis/Capes classification, which directed scientific production to periodicals in the higher categories, or because of the rise in

${ }^{15} \mathrm{As}$ a general rule for all areas, these are the guidelines established for the dimensioning of each category: $\mathrm{A} 1<\mathrm{A} 2, \mathrm{~A} 1+\mathrm{A} 2<25 \%, \mathrm{~A} 1+\mathrm{A} 2+\mathrm{B} 1<50 \%$. 
scientific publication and research during that period, the fact is that there was significant growth in scientific production of greater quality per capita, measured by the international nature and selectivity of the periodicals in which it was published. Lastly, the $0.53 \mathrm{~A} 1 /$ per capita registered in the area of Political Science is close to the 0.60 shown by the area of Biological Sciences III, the leading area in Brazilian scientific production today ${ }^{16}$.

The information presented by the SCImago Journal \& Country Rank allows this to be viewed from another angle, which enables us to grasp the evolution of the scientific production of Brazilian Political Science ${ }^{17}$. Constituted from the Scopus database, which collects information on publications in scientific periodicals of all areas of knowledge, ranking periodicals according to their volume of production, impact factor (SJR), citations and H-index, the SCImago records allow a comparison of journals, countries and areas of knowledge to be made, measuring intellectual production and its impact on the international scientific community.

The graph below shows the position of Brazilian Political Science in the ranking of the discipline's international community, considering two indicators: the volume of articles published in journals indexed and included in the Scopus database, and citations subsequent to these texts in new articles published in journals included in the database. The period of observation is 1998-201218. Initially, what draws attention is the significant evolution of Brazilian Political Science when the volume of production in published periodicals included in the Scopus database is considered. In 1998, Brazilian Political Science came $44^{\text {th }}$ in the international Political Science community in terms of publications. PS/BR showed a rising trend, reaching $16^{\text {th }}$ place in 2012 and rising by 28 places during this period. This notable evolution in a limited period of time could likely be explained by an improvement in the indexation of Brazilian journals and their inclusion into the Scopus database, but most of all by the significant growth in scientific research geared towards more selective and internationalised journals (captured in the previously portrayed information on the rise of A1 production per capita). Since

\footnotetext{
${ }^{16} \mathrm{http}: / /$ avaliacaotrienal2013.capes.gov.br/resultados/planilhas-comparativas.

$17 \mathrm{http}: / /$ www.scimagojr.com/index.php.

18 The Scopus database does not display information pertaining to 2003.
} 
2004, Brazil has consolidated itself in the leading position in Latin America, surpassing Argentina, Chile and Mexico in indexed publications.

Graph 08. Position of Brazilian PS \& IR in the Scopus ranking: documents and citations - 1998-2012

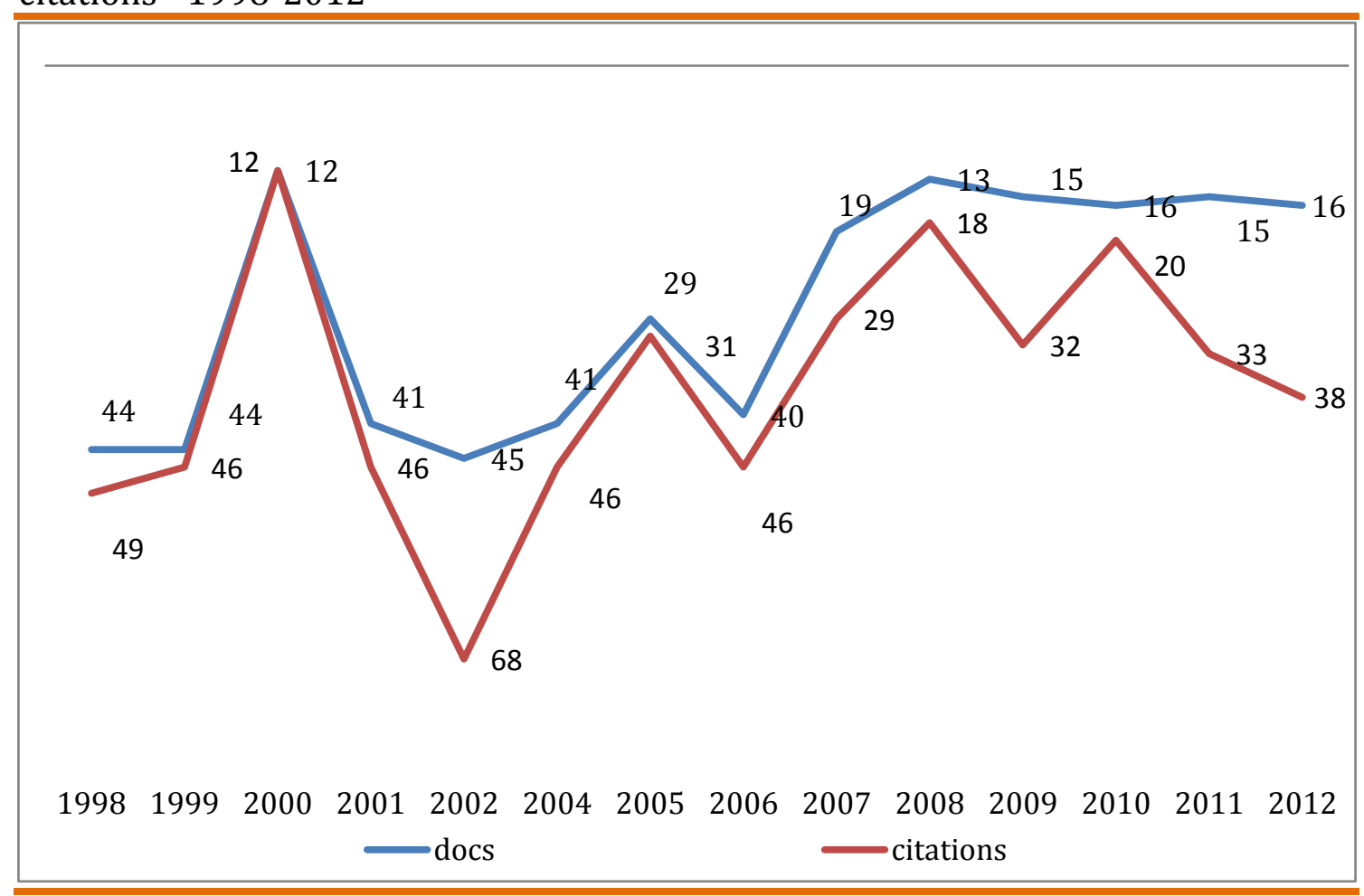

Source: SCImago/Scopus.

On the other hand, when one considers the citations of Brazilian researchers registered, the position of PS/BR shows irregular behaviour, oscillating from the $68^{\text {th }}$ position in 2002 to the $20^{\text {th }}$ (2010) and finally settling at $38^{\text {th }}$ in the last record (2012). An interpretation of this combined information seems clear: Brazilian Political Science is publishing more, but its scientific production has low repercussion in the international community, measured by the number of citations of its articles.

What reasons might explain the limited repercussion of Brazilian publications in the area? The fact that they are in Portuguese, which has limited readership in the rest of the world, might be partly responsible. Although the participation of Brazilian periodicals in the A1 (6.9\%) and A2 (1.1\%) categories is low, the fact that a disproportionate amount of Brazilian production is published in Brazilian journals probably contributes to limiting its international visibility. 
Another factor to consider is international collaboration. The creation of international research networks, resulting in articles with international co-authors being published, boosts the production's visibility and its capacity to generate citations by the discipline's international community. However, the frequency of international collaboration in the scientific production of Brazilian Political Science is limited and at a lower level when compared to its Chilean and Mexican counterparts.

Graph 09. International collaboration as a percentage of total production

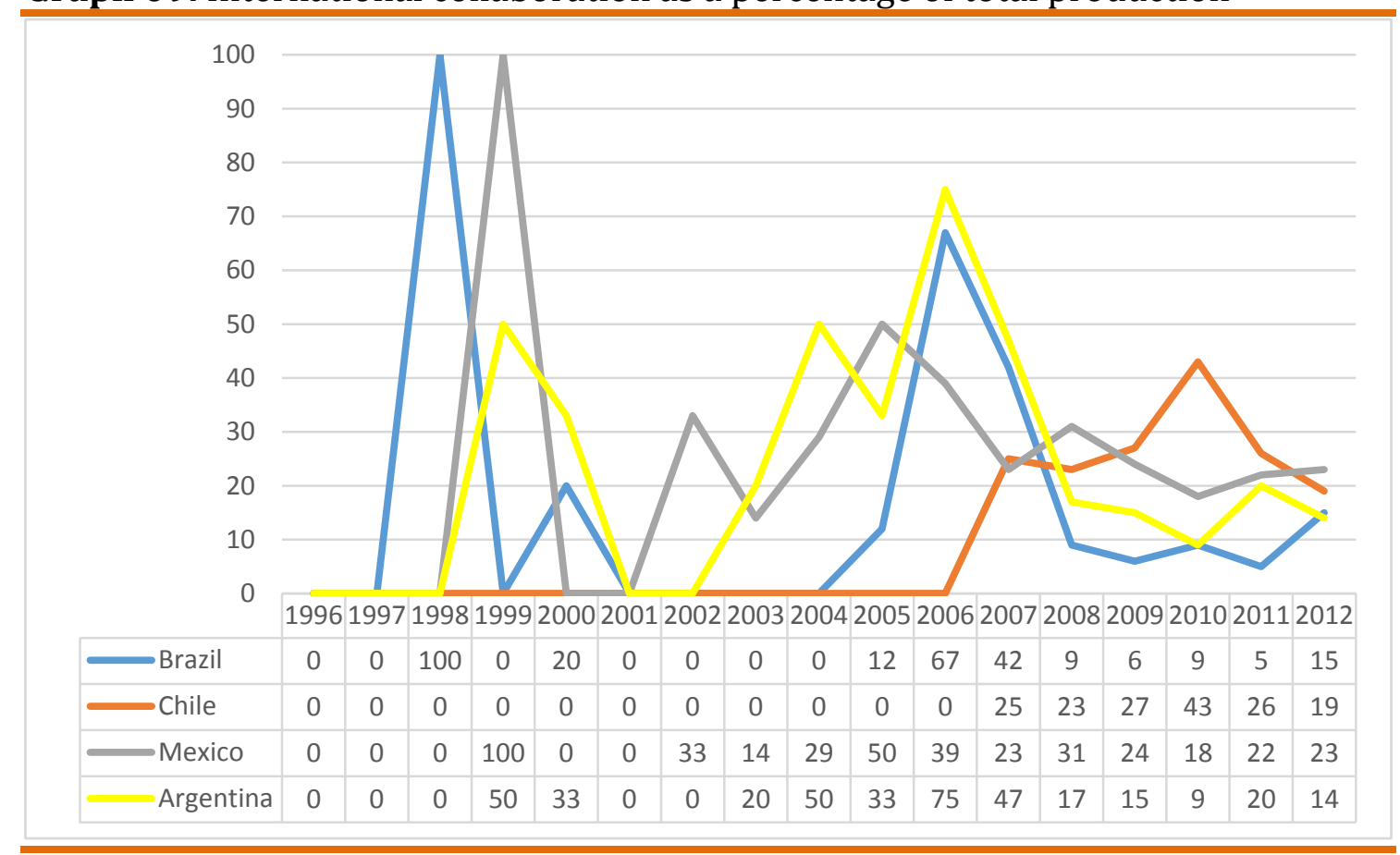

Source: SCImago/Scopus.

An additional angle through which to analyse international collaboration can be obtained by comparing the information on co-authorships among researchers of the three previously compared Brazilian areas (Political Science, Anthropology and Sociology). The result of this procedure can be observed in Graph 10, below. 
Graph 10. International collaboration in Brazilian political science, anthropology and sociology

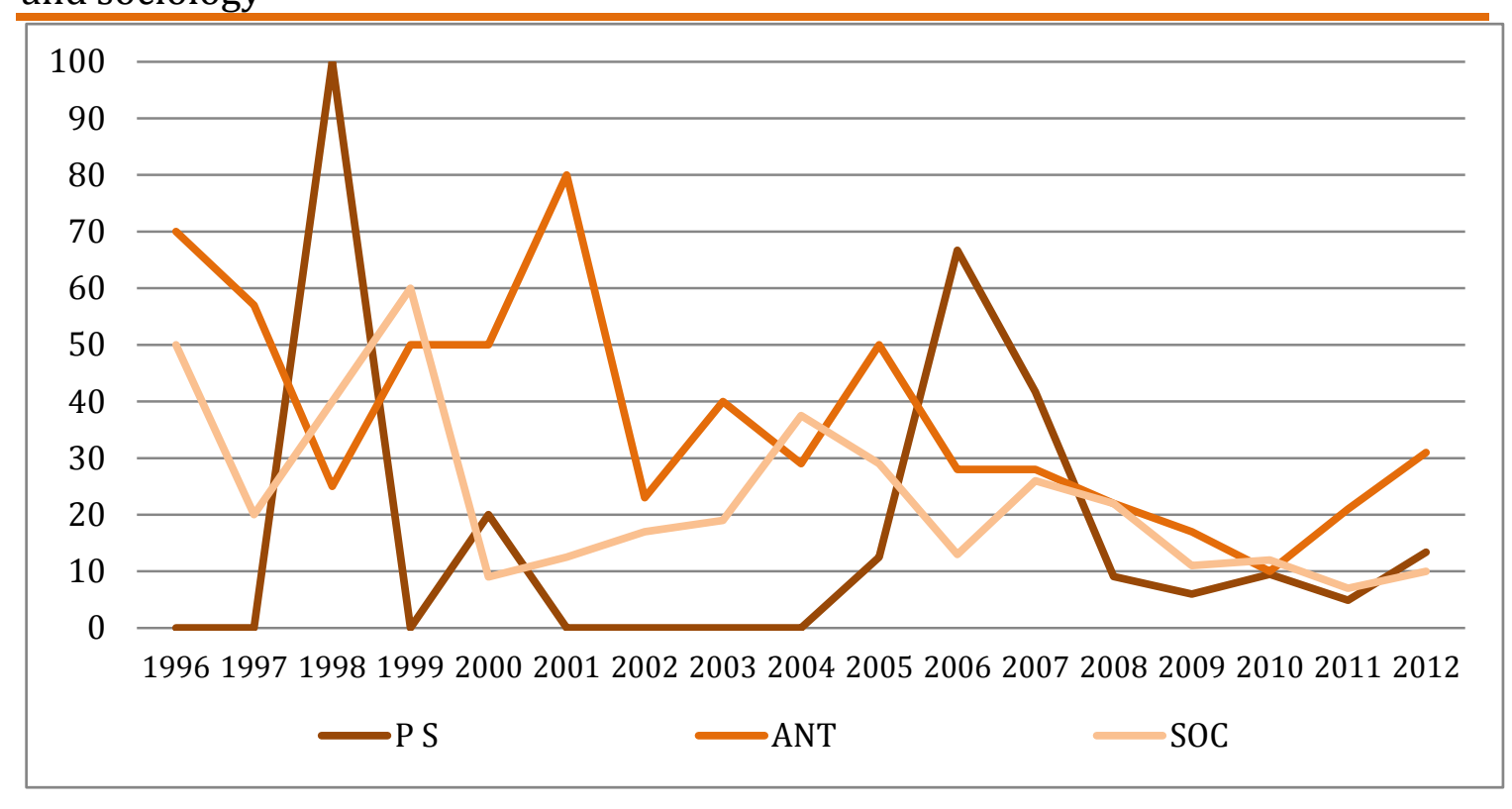

Source: SCImago/Scopus.

Once again, two isolated moments of greater international cooperation (1998 and 2006-2007) stand out from a dominant pattern of isolation and lower frequency of academic interactions with researchers from other countries. When we consider the average percentage of documents published by authors from more than one country in the $1996 / 2012$ period, we see less interaction between Brazilian political scientists and their international peers $(16.7 \%)$ than sociologists (23\%) and anthropologists (37\%) and theirs.

Aside from international collaboration, the publishing of articles by international authors in Brazilian journals could be an opportunity to increase their prestige in the international community and therefore maximise the visibility of the production of Brazilian researchers. The graph below presents the proportion of articles authored by foreign researchers in the main Brazilian periodicals. Only journals in Qualis category A1 in the area of Political Science and International Relations in the 2000-2010 period were considered. By way of comparison, information on the Revista de Ciencia Política edited by the Catholic University of Chile, equally classified as A1, is also presented. 
Graph 11. Participation of foreign authors as a percentage of articles published in Brazilian journals ${ }^{19}$ - 2000-2010

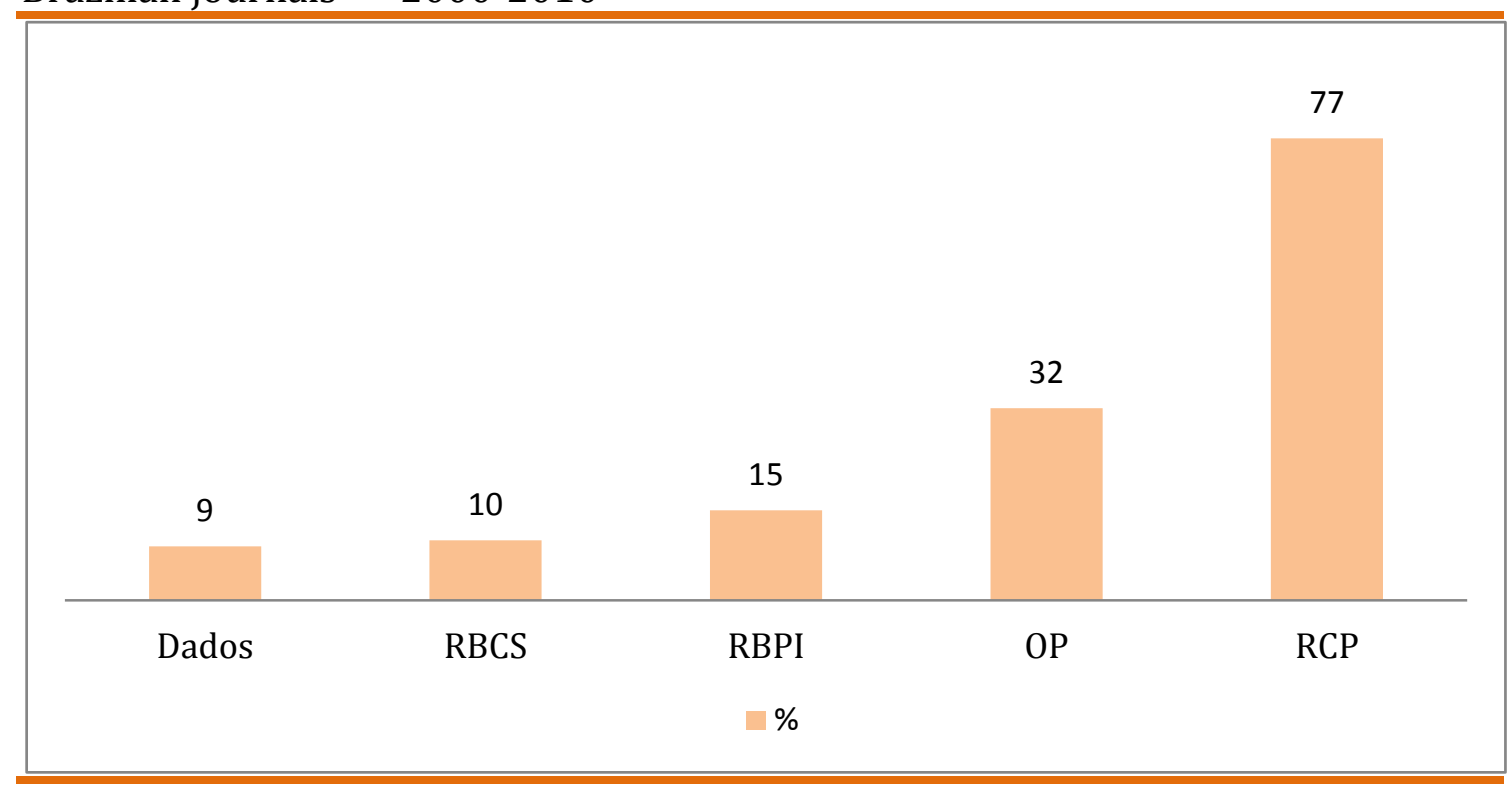

Source: Scielo. Data processed by the author.

The main Brazilian periodicals, classified in the highest Qualis/Capes category, seem to be journals that publish work by Brazilian researchers in Portuguese. In spite of the quality, tradition and reputation acquired, participation by international authors in the main Brazilian scientific periodicals in the Area of Political Science and International Relations is minimal. In 10 years, only $9 \%$ of articles published in Dados, $10.3 \%$ of those published in RBCP and 14.9\% of those published in RBPI were authored by or co-authored with foreign researchers. Opinião Pública was the exception to this rule, with almost one third of its articles co-authored with international authors. The contrast is evident when this information is compared against data from the Chilean Revista de Ciencia Política. In it, around $3 / 4$ of articles published had the participation of non-Chilean authors in the same period.

As well as the authors' language and nationality, it can be equally relevant to consider the themes of the articles published by Brazilian political scientists in Brazilian periodicals classed in the highest Qualis/Capes category. Since the aim is now to assess the dimension of the main themes dealt with, we chose not to consider journals of a wider scope such as RBCS and Lua Nova, whose inclusion of themes from Anthropology and Sociology would make any comparison biased. The

19 Dados; RBCS: Revista Brasileira de Ciências Sociais; RBPI: Revista Brasileira de Política Internacional; OP: Opinião Pública; RCP: Revista de Ciência Política 
same is the case with RBPI and Contexto Internacional and International Relations themes. Thus, two A1 journals (OP and Dados) and two A2 journals (BPSR and RSP), more focused on Political Science themes, were considered. The triennial period observed was 2010/12.

Table 03. Distribution of articles by themes, A1 and A2 Political Science journals ${ }^{20}$ - 2010-2012

\begin{tabular}{lcccc}
\hline & OP & Dados & BPSR & RSP \\
\hline Brazilian politics & 71.2 & 64.2 & 69.0 & 52.7 \\
Political Theory (normative) & 8.5 & 14.8 & 6.9 & 31.2 \\
Political Theory (positive) & - & - & - & 5.4 \\
Methodology & 1.7 & - & - & 1.0 \\
Comparative politics & 18.6 & 21.0 & 24.1 & 9.7 \\
\hline
\end{tabular}

Source: Scielo. Data processed by the author.

Articles on "Brazilian politics" were equivalent to around $2 / 3$ of the scientific production in journals of the higher Qualis categories in 2010/12. The social sciences usually deal with their objects of study in a certain territory, and it is expected that "Brazilian politics", "Brazilian society" and "Brazilian history" etc. should be relevant themes, and certainly themes of great interest to Brazilian political scientists, anthropologists, sociologists and historians. On the other hand, the small amount of work on positive political theory and methodology, as well on more comparative approaches, seems to reveal the scarce nomological ambitions of Brazilian political scientists. The profession of scientist of politics consists in attempting to build general causal inferences to explain the formation, stability and change process of political institutions. In the last two decades, Brazilian Political Science has made significant advances in knowledge on the morphology of Brazilian "coalition presidentialism", party discipline in Brazil, federalism and intergovernmental relations in Brazil, the behaviour of Brazilian voters, and the growth of social expenditures and public policies in Brazil21. The numbers relative to the scientific production published in Brazilian journals show a vocation for the

\footnotetext{
${ }^{20}$ Dados, RBCS, RBPI, OP and RCP.

${ }^{21}$ A more disaggregated analysis of Brazilian production in this area is beyond of the scope and size of this article. An example of this can be seen in the excellent work by Nicolau and Oliveira (2013) and Leite and Codato (2013).
} 
study of a specific national case. It seems evident that this option comes at a price, in the shape of limited repercussion in the international community. It is unlikely that journals of a higher impact factor will publish many articles on Brazilian politics. Except perhaps for Brazilianists, few authors will search for articles on Brazilian politics, published in Brazilian journals, to cite in their publications.

\section{Conclusion}

What difference does greater or lesser institutionalisation of a discipline make? This article has attempted to analyse the process of institutionalisation of Brazilian Political Science from the creation of the first few postgraduate programmes in the area at the end of the 1960s. By institutionalisation, we understand the constitution of professional spaces - represented by scientific associations and academic institutions, which distance the researcher's craft from dilettante amateurism - and, parallel to that, the emergence of an assessment system based on peer judgement.

As well as the late constitution of its scientific association, a disparity can be observed between the expansion of Political Science postgraduate institutions and that of areas such as Sociology or Anthropology. This has repercussions, which are that Political Science has a smaller presence in Brazil and that there has been a deficit in training doctors, which has impacted on the formation of new postgraduate institutions.

Regarding the institutional assessment, Brazilian Political Science has felt the effects of its late institutionalisation, having been awarded its first sevens only in 2010. In spite of scientific productivity indicators showing very significant positive variance, we see low visibility indexes and a low impact of this production in the field's international community. The fact that a significant part of the production is published in Portuguese, by Brazilian journals, with little international collaboration, addressing themes that are territorially delimited and related to "Brazilian politics", with a limited amount of production focusing on political theory (whether normative or positive) or compared studies, might help to explain the yet restricted repercussion of the growing scientific production of Brazilian Political Science. 
Translated by Priscila Moura Submitted in May 2014 Accepted in August 2014

\section{References}

ALMOND, Gabriel(1996), Political science: the history of the discipline. In: GOODIN, Robert and KLINGEMANN, Hans-Dieter. A New Handbook of Political Science. Oxford: Oxford University Press.

ALTMAN, David (2012), Where is knowledge generated? On the productivity and impact of political science departments in Latin America. European Political Science. № 11, pp. 71- 87, European Consortium for Political Research.

BARRY, Brian (1996), Political theory, old and new. In: GOODIN, Robert and KLINGEMANN, Hans-Dieter. A New Handbook of Political Science. Oxford: Oxford University Press.

BIANCHI, Álvaro (2014), Avaliação acadêmica: muito além do jardim. Available at http://blogconvergencia.org/blogconvergencia/?p=1915. Retrieved on July 25, 2014.

BRANDÃO, Gildo Marçal (2007), Linhagens do pensamento político brasileiro. São Paulo: Hucitec.

BULCOURF, Pablo e CRUZ VAZQUEZ, Juan (2004), La Ciencia Política como profesión. PostData. Vol. 10, December.

CARVAlHO, José Murilo de (1980), A construção da ordem. Rio de Janeiro: Ed. Campus.

DOGAN, Mattei (1996), Political science and the other social sciences. In: GOODIN, Robert and KLINGEMANN, Hans-Dieter. A New Handbook of Political Science. Oxford: Oxford University Press.

FAVRE, Pierre and LEGAVRE, Jean-Baptiste (1998), Enseigner la Science Politique. Paris: L'Harmattan.

FAVRE, Pierre (1985), Histoire de la science politique. In: GRAWITZ, Madeleine and LECA, Jean. Traité de Science Politique. Paris: Presses Universitaires de France.

FORJAZ, Maria Cecília Spina (1997), A emergência da Ciência Política acadêmica no Brasil: aspectos institucionais. Revista Brasileira de Ciências Sociais. Vol. 12, № 35.

GOODIN, Robert (2009), The state of discipline, the discipline of the State. In: GOODIN, Robert. The Oxford Handbook of Political Science. Oxford: Oxford University Press. 
GOODIN, Robert and KLINGEMANN, Hans-Dieter (1996), A New Handbook of Political Science. Oxford: Oxford University Press.

GRAWITZ, Madeleine and LECA, Jean (1985), Traité de Science Politique. Paris: Presses Universitaires de France.

LAMOUNIER, Bolivar (1982), A ciência política no Brasil: roteiro para um balanço crítico. In: LAMOUNIER, Bolivar (Ed). A Ciência Política nos anos 80. Brasília, UnB.

LEITE, Fernando e CODATO, Adriano (2013), Autonomização e institucionalização da Ciência Política brasileira: o papel do sistema Qualis-Capes. Agenda Política. São Carlos: Vol. 01, № 01.

MADEIRA, Rafael (2013), Quem faz e como se faz Ciência Política no Brasil: notas de pesquisa. Bogotá: Sétimo Congresso Latino Americano de Ciência Política, ALACIP.

MICELI, Sérgio (1995), História das ciências sociais no Brasil. São Paulo: Sumaré. Vol. 02.

NICOLAU, Jairo e OLIVEIRA, Lilian (2013), A Produção da Ciência Política Brasileira: Uma Análise dos Artigos Acadêmicos. $37^{\circ}$ Encontro Anual da Associação Nacional de Pós-Graduação e Pesquisa em Ciências Sociais [ANPOCS]. Águas de Lindóia/SP, September. pp. 23-27.

PÉREZ-LIÑAN, Aníbal (2010), Temas de investigación y perspectivas de la ciencia política latinoamericanista en Estados Unidos. Ponencia presentada en el seminario El estado de la Ciencia Política en América Latina: Desafíos y oportunidades de la docencia y la investigación en perspectiva comparada. Fundación Global Democracia y Desarrollo, República Dominicana.

PIRES, Valdemir et al. (2014), Dossiê - Campo de Públicas no Brasil: definição, movimento constitutivo e desafios atuais. Administração Pública e Gestão Social. Vol. 06, № 03, Jul-Sep 2014, pp. 110-126.

SARTORI, Giovanni (1984), La Política. México: Fondo de Cultura Económica.

SCHWARTZMAN, Simon (1982), As bases do autoritarismo brasileiro. São Paulo: Difel.

SKINNER, Quentin (1978), The foundations of modern political thought. Cambridge: Cambridge University Press.

TAVARES de ALMEIDA, Maria Hermínia (2005), Ciência Política no Brasil, avanços e desafios. In: MARTINS, Carlos Benedito (org). Para onde vai a Pós-graduação em Ciências Sociais no Brasil. Bauru: Edusc. 
TRINDADE, Hélgio (2012), Ciências Sociais no Brasil. Diálogos com mestres e discípulos. Brasília, Anpocs/Liber.

TRINDADE, Hélgio (org)(2007), As Ciências Sociais na América Latina em Perspectiva Comparada. 2 ${ }^{\mathrm{a}}$ Ed. rev., Porto Alegre: Editora UFRGS.

VON BEYME, Klaus (1996), Political theory: empirical political theory. In: GOODIN, Robert and KLINGEMANN, Hans-Dieter. A New Handbook of Political Science. Oxford: Oxford University Press. 